\title{
НЕЗАЛЕЖНІСТЬ УКРАЇНИ В СУЧАСНОМУ СУСПІЛЬНОМУ ДИСКУРСІ
}

\author{
https://doi.org/10.37472/2707-305X-2021-3-2-17-7
}

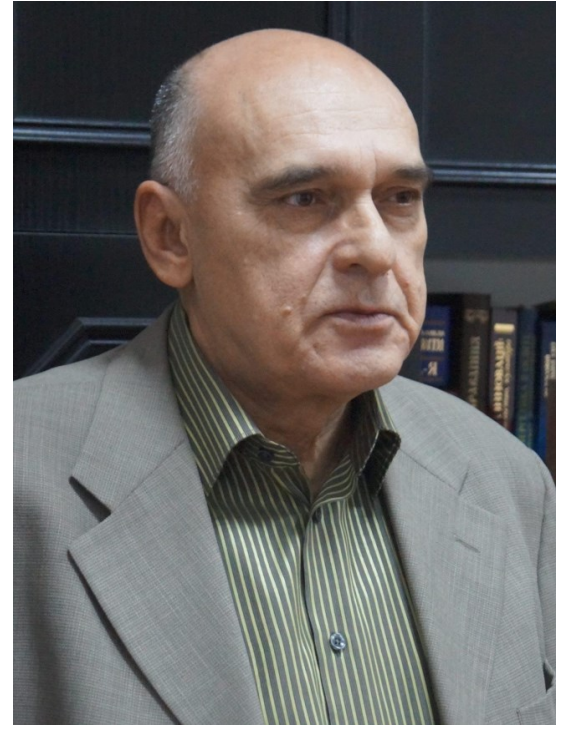

СЛЮСАРЕВСЬКИЙ

\section{Микола Миколайович}

кандидат психологічних наук, член-кореспондент НАПН

України, директор Iнституту соціальної та політичної психології Національної академії педагогічних наук України, м. Київ, Україна
Анотачія. Обговорюються оприлюднені під час урочистого засідання Вченої ради Інституту соціальної та політичної психології Національної академії педагогічних наук України результати масового репрезентативного опитування громадської думки щодо державної незалежності України та ї̈ символів. Протягом 1-12 серпня 2021 р. опитано 1200 громадян за вибіркою, що репрезентує доросле населення України. Показано стійку тенденцію зростання частки громадян, які відносять проголошення незалежності України в 1991 році до здобутків українського народу, що найбільще заслуговують бути предметом його національної гордості. Ця тенденція найбільше простежується серед людей віком від 30 до 55 років і відображає процеси, що відбуваються в суспільній свідомості певною мірою спонтанно, без цілеспрямованих формувальних зусиль з боку державних та інших інститутів впливу. На основі порівняння даних опитування з результатами Всеукраїнського ресерендуму 1 грудня 1991 р., розрахованими відносно загальної кількості дорослого населення України, продемонстровано тенденцію зростання в українському суспільстві підтримки Акта проголошення державної незалежності.

Ключові слова: Незалежність України; відновлення державної незалежності; громадська думка; моніторинг; національні символи.

Нинішнього літа Україна відзначила тридцяту річницю з дня проголошення, або - як справедливо наголошує чимало істориків та політологів - відновлення державної незалежності. 3 нагоди такої визначної події Інститут соціальної та політичної психології Національної академії педагогічних наук України запланував проведення низки заходів, зокрема IX міжнародного конкурсу молодих науковців «Уявне, архетипи та публічне управління», IV Міжнародної конференції «Психічне здоров'я: глобальні виклики XXI століття», V круглого столу з міжнародною участю «Історія в нас і ми в історії», XIX Всеукраїнської наукової конференції «Проблеми політичної психології та її роль у становленні громадянина Української держави».

Також у межах запланованих до 30-річчя Незалежності України заходів 26 серпня 2021 р. відбулося урочисте засідання Вченої ради Інституту, під час якого я мав нагоду оприлюднити та прокоментувати деякі результати масового репрезентативного опитування громадської думки, проведеного під моїм керівництвом 1-12 серпня цього року, безпосередньо пов'язані з проголошенням державної незалежності України у 1991 році. Хочу наголосити, що такі опитування на тему «Громадсько-політична ситуація в Україні» Інститут проводить у моніторинговому режимі (тобто на регулярній, щорічній основі) із середини 1990-х років. І це дає змогу відстежувати трансформації суспільної свідомості у тривалій часовій ретроспективі та перспективі.

Передусім спостерігаємо на диво стійку тенденцію зростання частки громадян, які відносять проголошення незалежності України 
в 1991 році до здобутків українського народу, що найбільше заслуговують бути предметом його національної гордості (ІСПП НАПН України, 2021). Список здобутків, який ми пред'являємо тепер респондентам у вигляді готових формулювань, нараховує близько 20 найменувань. Він був складений на основі пропозицій, згенерованих самими громадянами у відповідях на відкриті запитання ще 20 років тому, і потім лише дещо змінювався (Слюсаревський та ін., 2019).

На момент останнього опитування проголошення державної незалежності увійшло до трійки найбільш значущих здобутків народу, переваживши такі події як Революція Гідності, перемога у Другій світові війні, а тим паче Помаранчеву революцію, історію боротьби УПА, Українську революцію 1917-1921 років (табл. 1).

Тенденція збільшення частки респондентів, які вбачають у проголошенні незалежності України визначний історичний здобуток, є показовою під різними кутами зору.

По-перше, цілеспрямованого пропагування цієї події протягом багатьох років не було. Навпаки, її значення часом навіть применшувалося наприклад, у період ейфорії від Помаранчевої революції. Отже, значущість незалежності зростала в суспільній свідомості почасти або й переважно спонтанно.

Розподіл відповідей на запитання «Які здобутки українського народу, на Вашу думку, найбільще заслуговують сьогодні бути предметом його національної гордості?»

Табличя 1 (у \% до загальної кількості громадян, що досягли 18-річного віку)

\begin{tabular}{|c|c|c|c|c|}
\hline & $\begin{array}{l}\text { Вересень } \\
2015 \text { р. }\end{array}$ & $\begin{array}{l}\text { Вересень } \\
2018 \text { р. }\end{array}$ & $\begin{array}{l}\text { Вересень } \\
2019 \text { р. }\end{array}$ & $\begin{array}{l}\text { Серпень } \\
2021 \text { р. }\end{array}$ \\
\hline $\begin{array}{l}\text { Творчість великих українських поетів, письменників, } \\
\text { композиторів та виконавців (Т. Шевченко, Леся Українка, } \\
\text { І. Франко, М. Лисенко, С. Крушельницька та ін.) }\end{array}$ & 54,5 & 56,5 & 57,8 & 52,0 \\
\hline Історія українського козацтва, Запорозької Січі & 42,2 & 47,0 & 47,8 & 47,2 \\
\hline Проголошення незалежності України у 1991 році & 32,7 & 37,4 & 39,1 & 42,8 \\
\hline Досягнення українських спортсменів & 36,9 & 48,0 & 47,5 & 38,8 \\
\hline Збройні сили України & 23,4 & 32,3 & 34,3 & 36,4 \\
\hline $\begin{array}{l}\text { Вершинні досягнення української народної творчості } \\
\text { (думи, пісні, декоративно-вжиткове мистецтво, народна } \\
\text { архітектура тощо) }\end{array}$ & 37,7 & 38,4 & 42,1 & 35,3 \\
\hline Волонтерський рух & $\begin{array}{l}\text { не було у } \\
\text { списку }\end{array}$ & 36,0 & 36,7 & 33,7 \\
\hline $\begin{array}{l}\text { Революція Гідності 2014-2015 років та збройна відсіч } \\
\text { російській агресії }\end{array}$ & 36,4 & 28,4 & 28,3 & 33,0 \\
\hline Перемога у Другій світовій війні & 43,8 & 46,7 & 44,5 & 29,4 \\
\hline $\begin{array}{l}\text { Діяльність видатних провідників українського національно- } \\
\text { виз-вольного руху (М. Грушевський, В. Винниченко, } \\
\text { С. Петлюра та ін.) }\end{array}$ & 17,4 & 21,9 & 27,2 & 24,6 \\
\hline Міжнародне визнання України в сучасному світі & 24,2 & 23,7 & 27,3 & 24,1 \\
\hline $\begin{array}{l}\text { Боротьба українських правозахисників (П. Григоренко, } \\
\text { Л. Лук'яненко, М. Руденко, В. Чорновіл та ін.) проти } \\
\text { тоталітарного режиму }\end{array}$ & 21,6 & 24,0 & 27,6 & 23,3 \\
\hline Досягнення української космонавтики & 17,0 & 20,6 & 18,3 & 17,8 \\
\hline Помаранчева революція 2004 року & 13,2 & 10,9 & 13,6 & 17,6 \\
\hline $\begin{array}{l}\text { Історія створення та боротьби УПА (Української } \\
\text { повстанської армії) }\end{array}$ & 15,2 & 16,1 & 14,9 & 17,5 \\
\hline $\begin{array}{l}\text { Повоєнна відбудова народного господарства } \\
\text { (у 2-й половині 1940-х років) }\end{array}$ & 20,9 & 18,8 & 17,4 & 17,2 \\
\hline Вітчизняна система освіти & 6,1 & 8,2 & 7,2 & 12,2 \\
\hline $\begin{array}{l}\text { Трудові досягнення робітників і селян Радянської України } \\
\text { (П. Ангеліна, М. Демченко, О. Стаханов, О. Гіталов та ін.) }\end{array}$ & 14,4 & 14,2 & 15,3 & 11,5 \\
\hline Українська революція 1917-1921 років & 6,0 & 6,9 & 6,3 & 9,1 \\
\hline Iнше & 2,7 & 1,1 & 1,4 & 2,4 \\
\hline Важко відповісти & 6,1 & 4,0 & 3,1 & 4,1 \\
\hline
\end{tabular}


По-друге, найбільше ця тенденція простежується, як не дивно, не серед молоді, яка зазвичай налаштована найбільш патріотично, а серед людей віком від 30 до 55 років, тобто найдієздатнішої частини суспільства. По-третє, усвідомлення історичного значення цієї події кореспондує з відповідями на інші запитання, що стосуються української незалежності. Хоча в оцінці того, чи $\epsilon$ сьогодні Україна справді незалежною державою, громадська думка стагнує, і частка ствердних відповідей протягом кількох років рідко перевищує $30 \%$, відповіді на запитання «А чи вважаєте Ви, що Україна спроможна існувати як справді незалежна держава?» демонструють стійкі оптимістичні настрої громадян. Від двох третин до трьох чвертей респондентів зберігають цей оптимізм попри всі труднощі, що супроводжують українську незалежність (рис. 1).

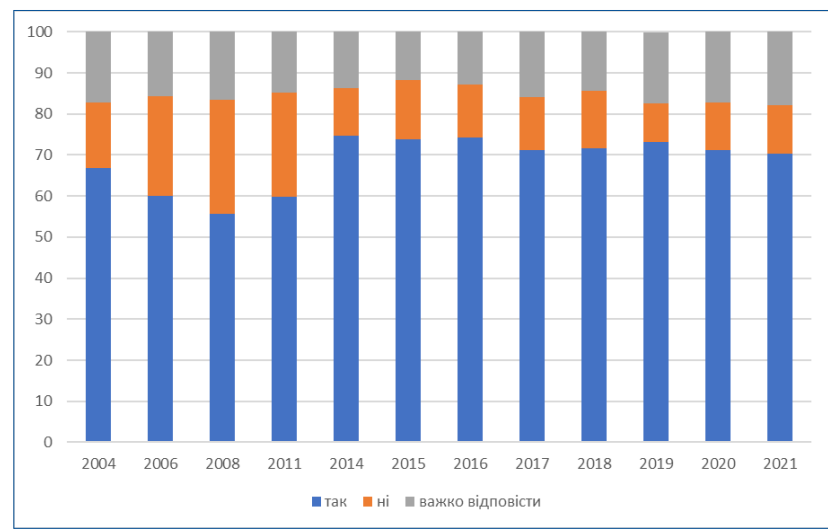

Рис. 1. Розподіл відповідей на запитання «А чи вважаєте Ви, що Україна спроможна існувати як справді незалежна держава?» (у \%)

Результати моніторингу дають також змогу спростувати деякі міфи, що культивуються в інформаційному просторі. Наприклад, міф про те, що 1 грудня 1991 р. за незалежність проголосувало понад 90 \% українців, а нині громадська підтримка незалежності, мовляв, є значно слабшою.

Насправді за незалежність проголосувало $90 \%$ учасників референдуму, які становили $76,03 \%$ усього дорослого населення віком
18 років і старше. Здавалось би, різниця невелика, і там, і там - більшість. Але шкідливість цього міфу величезна. Майже три десятиріччя соціологи ставлять громадянам гіпотетичне запитання: «Як би Ви проголосували, якби сьогодні проводився референдум про незалежність України?» і отримують 70 і менше відсотків відповідей на користь незалежності. А потім за активного сприяння медіа в суспільстві насаджується думка про те, що актуальна підтримка незалежності нібито значно менша, ніж була у 1991 році.

Тим часом очевидно, що таке формулювання фактично зазіхає на Статтю 1 Конституції, де чітко визначено, що Україна $€$ незалежною державою, і некоректне з наукового погляду. Багаторічний досвід проведення опитувань показує, наскільки принциповою $\epsilon$ різниця між відповідями на запитання, сформульованими в умовний спосіб i, так би мовити, в імперативному вигляді. Тому для чистоти порівняння слід формулювати запитання саме так, як воно ставилося на референдумі 1991 року: «Чи підтверджуєте Ви Акт проголошення незалежності України?».

Це, власне, ми і робимо в наших анкетах, тільки додаємо слова «прийнятий у 1991 році». I коли дається таке формулювання, то отримуємо зовсім іншу картину. З'ясовується, що частка громадян, які підтверджують Акт проголошення незалежності України, порівняно з 1991 роком не зменшується, а, навпаки, збільшується. Збільшується стабільно, і тепер справді становить понад 90 \% (табл. 2).

Акт проголошення незалежності України підтверджує переважна більшість громадян в усіх регіонах - Західному (98,1\%), Центральному (95,2\%), Східному (91,3\%) та Південному (88,8\%).

Отримані й інші дані моніторингу, які переконливо засвідчують, що істинне значення, справжній історичний масштаб здобуття Україною незалежності нині очевидний не тільки для вузької групи політичних ентузіастів. Це незапе-

Таблиия 2

Розподіл відповідей на запитання «Чи підтверджуєте Ви прийнятий у 1991 році Акт проголошення незалежності України?» (у \% до загальної кількості громадян, що досягли 18-річного віку)

\begin{tabular}{|l|c|c|c|c|c|c|c|c|c|}
\hline Відповідь & $\begin{array}{c}\text { Результати } \\
\text { Всеукраїнського } \\
\text { референдуму } \\
1991 \text { року }\end{array}$ & 2014 & 2015 & 2016 & 2017 & 2018 & 2019 & 2020 & 2021 \\
\hline так & 76,03 & 92,4 & 91,0 & 92,1 & 93,1 & 92,6 & 95,9 & 95,3 & 94,0 \\
\hline ні & 6,4 & 7,6 & 9,0 & 7,9 & 6,9 & 7,4 & 4,1 & 4,7 & 6,0 \\
\hline
\end{tabular}


речний факт, прописаний у масовій свідомості українського народу як одне з його найвагоміших надбань.

\section{СПИСОК ВИКОРИСТАНИХ ДЖЕРЕЛ}

Інститут соціальної та політичної психології НАПН України. (n.d.). Головна. https://ispp.org.ua/ Інститут соціальної та політичної психології НАПН України. (2021, 19 серпня). 3 кожним роком зростає кількість громадян, які вважають проголошення Незалежності України предметом національної гордості: прес-реліз за результатами опитування громадської думки. https://bit.ly/3awFd1R

Слюсаревський, М., Гуменюк, О., Дворник, М., \& Черниш, Л. (2019). Соціальна ситуація в Україні: особливості відображення трансформаційних процесів у громадській думці (2014-2018) : довідник. Київ: Талком. https://ispp.org.ua/wp-content/ uploads/2020/10/SocialSituationDovidnik.pdf

\section{UKRAINE'S INDEPENDENCE IN MODERN PUBLIC DISCOURSE}

Mykola Slyusarevskyy

PhD in Psychology, Corresponding Member of NAES of Ukraine, Director, Institute for Social and Political Psychology of the National Academy of Educational Sciences of Ukraine, Kyiv, Ukraine

Abstract. The results of a mass representative public opinion poll on the state independence of Ukraine and its symbols, published during a solemn meeting of the Academic Council of the Institute of Social and Political Psychology of the National Academy of Educational Sciences of Ukraine, are discussed. During August 1-12, 2021, 1,200 citizens were interviewed in a sample representing the adult population of Ukraine. The steady tendency of growth of the share of citizens who attribute the proclamation of Ukraine's Independence in 1991 to the achievements of the Ukrainian people, which deserve to be the subject of their national pride, is shown. This trend mainly touches upon people aged 30 to 55. It reflects spontaneous processes in the public consciousness that occur without purposeful formative efforts by the state or other institutions of influence. Based on a comparison of the survey data with the results of the All-Ukrainian referendum on December 1, 1991, calculated on the total adult population of Ukraine, the author demonstrates the tendency of growth in Ukrainian society to support the proclamation of state independence.

Keywords: Independence of Ukraine; re-establishment of state independence; public opinion; monitoring; national symbols.

Дата публікації: 24 вересня 2021 р. 